Леся Рожак

Національна академія державного управління при Президентові України

Система публічних закупівель як ефективний інструмент електронного урядування для подолання корупції в Україні в контексті впровадження електронної демократії

У роботі викладено результати дослідження щодо впровадження системи публічних закупівель як ефективного інструменту електронного урядування, спрямованого на запобігання корупційним правопорушенням. Визначено ключові характеристики та особливості функціонування електронної системи закупівель ProZorro, а також іiі вплив на рівень розвитку е-урядування в Україні. Водночас надаються рекомендації щодо першочергових заходів із підвищення об'єктивності та прозорості процесів проведення публічних закупівель та розвитку електронної демократії в Україні.

Ключові слова: електронне урядування, електронна система закупівель ProZorro, електронна демократія, публічні закупівлі, корупиія

\title{
Public procurement system as an effective tool e-government to combat corruption in Ukraine in the context of e-democracy
}

\section{Lesia Rozhak, National Academy for Public Administration under the President of Ukraine}

The paper presents the results of a study on the implementation of the public procurement system as an effective tool of e-government aimed at preventing corruption offenses. The key characteristics and features of the ProZorro electronic procurement system, as well as its impact on the level of e-government development in Ukraine are identified. At the same time, recommendations are given on priority measures to increase the objectivity and transparency of public procurement processes and the development of e-democracy in Ukraine.

Keywords: e-government, ProZorro e-procurement system, e-democracy, public procurement, corruption

$\mathrm{K}$ онституція України закріплює набуття повноправного членства України в Свропейському Союзі та в Організації Північноатлантичного договору як одну із стратегічних цілей нашої держави. Курс на невідворотність євроінтеграційного процесу передбачає серйозні виклики пов'язані перш за все з адаптацією вітчизняного законодавства до європейських стандартів, зокрема, у сфері реалізації державної інформаційної політики. Так, у межах реалізації Угоди про асоціацію Україна має забезпечити комплексний розвиток електронного урядування відповідно до європейських вимог.

Електронне врядування, зокрема, впровадження електронних послуг - одна 3 вагомих складових реформи державного управління. Головна мета переведення адміністративних послуг в електронний формат - це формування ефективного апарату державного управління. Сутність електрон- ного врядування полягає в інноваційному здійсненні державного управління 3 використанням сучасних інформаційно-комунікаційних технологій. Слід зазначити, що формулою електронного урядування $\epsilon$ поєднання електронного уряду з електронною демократією (Електронна демократія, 2008, c. 87).

Україна, незважаючи на складну політичну та економічну ситуацію, поступово рухається в напрямку розвитку інформаційного суспільства та у напрямку е-урядування, однак темпи їх впровадження у життєдіяльність суспільства є повільними, оскільки попит на електронні адміністративні послуги випереджає їх пропозицію. Згідно $з$ дослідженням $\mathrm{OOH}$ United Nations E-government Survey 2018 щодо розвитку електронного урядування (E-Government Development Index (EGDI)) Україна посіла 82 місце серед 193 країн, що свідчить про наявність позитивної динаміки (Барегамян, \& Карпі, 2019, с. 5). 
Покращенню позиції України на міжнародній шкалі розвитку електронного урядування сприяло впровадження такої складової розвитку е-урядування в Україні як електронна система публічних закупівель, що забезпечує їх прозорість, неупередженість, оперативність та високу ефективність. Прозора система публічних закупівель здатна забезпечити безперебійну взаємодію між усіма представниками економічної системи на макроекономічному рівні, а також сприяє економічним зрушенням (Трофименко, 2018, с. 24).

Законодавство 32015 року вивело електронну демократію та електронне урядування на новий рівень. Так, Закон України, що координує публічні закупівлі, зобов'язує проводити закупівельні процедури через електронну систему закупівель ProZorro. Основна ціль електронної системи публічних закупівель ProZorro - це запобігання корупції шляхом збільшення прозорості ринку та створення конкурентного середовища для отримання найкращої пропозиції (Одарченко, Лісніченко, \& Василець, 2018, с. 23).

Електронна система публічних закупівель дозволяє учасникам процедури в інтерактивному режимі реального часу за допомогою інтерфейсу електронного майданчика протягом 3 етапів брати участь у торгах, змагаючись за перемогу в тендері. Електронні публічні закупівлі мають здійснюватися за такими принципами, як добросовісна конкуренція серед учасників; максимальна економія та ефективність; відкритість та прозорість на всіх стадіях закупівель; недискримінація учасників; об'єктивна та неупереджена оцінка пропозицій конкурсних торгів; запобігання корупційним діям (Фалко, 2014, с. 49).

Система електронних закупівель $є$ ефективним засобом виявлення та протидії корупції завдяки численним інструментам моніторингу та аналізу публічних закупівель. Окрім того, система є унікальною і за своєю будовою, адже функціонує за співпраці 3 сторін - держави, бізнесу та громадськості. Відповідно до покладених на неї функцій, держава повинна сприяти прозорому та підзвітному закупівельному процесу, а також забезпечувати належне правове регулювання цієї сфери (Куц, 2017, с. 4).

Світова практика застосування відкритих електронних торгів свідчить, що використання конкурентних механізмів при здійсненні закупівель суттєво економить кошти від запланованих на закупівлю, дозволяє зробити процедуру витрат бюджетних коштів транспарентною і відкритою, тим самим підвищуючи рівень довіри підприємництва та громадського суспільства до публічного сектору (Семенченко, \& Дрешпак, 2017, с. 57).

На цій основі держава намагається сформувати свою сталу політику в цій сфері та реалізувати мету відновлення довіри суспільства до демократичних інституцій та їх ефективності. Як справедливо зазначається, демократія $\epsilon$ ефективною, тільки якщо народ довіряє тим, хто урядує, а ця довіра невідворотно втрачається, коли діяльність високопосадовців викликає підозру у корупції (Хавронюк, 2018, с. 2).

Проте, незважаючи на впровадження електронної системи публічних закупівель, виконання положень законів та зобов'язань уряду досі залишається значним викликом. Впровадження системи електронних закупівель в Україні повинне відбуватися одночасно 3 реалізацією комплексної програми інституційного розвитку (Нижній, 2017, с. 111). Окрім того, важливою в цьому контексті є систематизація нормативно-правової бази в сфері е-урядування, що дасть змогу усунути відставання державного регулювання цих суспільних відносин від потреб суспільства, а також дозволить наблизитись до якісної гармонізації національної правової системи із загальновизнаними міжнародними нормами та принципами щодо інформатизації та е-урядування (Клімушин, 2017, с. 78).

Підсумовуючи, варто відзначити, що запровадження системи електронних публічних закупівель як частини електронного урядування в Україні не лише полегшило життя громадянам у використанні власного часу, але й зменшило рівень корупції завдяки відкритості, об'єктивності та прозорості процесів й ліквідації бюрократизації. Вищеперелічені позитивні зрушення, у свою 
чергу, слугують підгрунтям для розвитку та ухвалення управлінських рішень за доелектронної демократії, що сприяє залу- помогою використання сучасних інфорченню громадян до процесу вироблення маційних комунікаційних технологій.

\section{БІБЛІОГРАФІЧНІ ПОСИЛАННЯ}

Барегамян, С. Х., \& Карпі, Ю. В. (2019). Електронне врядування на загальнодержавному, регіональному та місцевому рівнях: сучасний стан та перспективи впровадження в Україні. Державне управління: удосконалення та розвиток, 1. Відновлено з http://www.dy.nayka.com.ua.

Клімушин, П С. (2017). Стратегї̈ та механізми електронного урядування в інформачійному суспільстві. Харків: Вид-во ХарРІ НАДУ «Магістр».

Куц, А. Р. (2017). Шифр «Прозорі закупівлі»: Переведення закупівель в електронний формат як ефективний інструмент боротьби з корупиісю. НТУ «КПІ ім. І. Сікорського».

Лісніченко, О. О., \& Василець, К. К. (2018). Публічні закупівлі: опорний конспект лекцій. Харків: Харківський державний ун-т харчування та торгівлі. Відновлено 3 http://elib.hduht.edu.ua/handle/123456789/3738.

Нижній, Т. В. (2017). Публічні закупівлі в системі електронного урядування. Інвестиції: практика та досвід, 10. Відновлено 3 http://nbuv.gov.ua/UJRN/ipd_2017_10_24.

Семенченко А. І., \& Дрешпак, В. М. (2017). Електронне врядування та електронна демократія. Київ: ФОП Москаленко.

Трофименко, О. Г. (2018). Електронні закупівлі у контексті боротьби із корупцією в органах публічної влади в Україні в умовах євроінтеграції. Актуальні проблеми запобігання корупиії в реалізаиії положень Закону України «Про запобігання корупиї», матеріали регіонального науково-практичного круглого столу. Запоріжжя: ЗНУ.

Фалко, Ю. В. (2014). Організація державних закупівель: досвід та практика України. Університетські, наукові записки, 1. Київ.

Хавронюк, М. І. (2018). Науково-практичний коментар до Закону Украӥни «Про запобігання корупиії». Шифр: «Трембіта надії». (2008). Електронная демократія: сутність та основні етапи. Київ. 